\title{
受容体解析に向けたバイオナノ磁性粒子上へのタンパク質ディスプレイ
}

\author{
吉野知子, ${ }^{*}$ 松永 是
}

\section{Protein Display onto Nano-sized Bacterial Magnetic Particles for Receptor Analysis}

\author{
Tomoko Yoshino* and Tadashi MATSUnAGA \\ Department of Biotechnology, Tokyo University of Agriculture and Technology, \\ 2-24-16, Naka-cho, Koganei, Tokyo 184-8588, Japan
}

(Received June 17, 2009)

\begin{abstract}
Magnetic particles offer vast potential in ushering new techniques, especially in biomedical applications, as they can be easily manipulated by magnetic force. Magnetotactic bacteria synthesize nano-sized biomagnetites, otherwise known as bacterial magnetic particles (BacMPs) that are individually enveloped by a lipid bilayer membrane. BacMPs are ultrafine magnetite crystals (50-100 nm diameters) with uniform morphology produced by Magnetospirillum magneticum AMB-1. Based on our elucidations on the molecular mechanism of BacMP formation in M. magneticum AMB-1, functional nanomaterials have been designed. Through genetic engineering, functional proteins such as enzymes, antibodies, and receptors were successfully displayed onto BacMPs. Here, display techniques of functional proteins onto nano-sized BacMPs and its applications to ligand binding assays were described. Dopamine receptor, which is a member of $\mathrm{G}$ protein-coupled receptors, was successfully displayed onto BacMPs. This system makes possible the convenient acquisition of the native conformation of membrane proteins without the need for detergent solubilization, purification and reconstitution after cell disruption. Furthermore, estrogen receptor, which is one of nuclear receptors, was also displayed onto BacMPs. The assay using BacMPs displaying estrogen receptor could discriminate full agonists, partial agonists, or antagonists. The elucidation of the mechanism of BacMP synthesis has provided a roadmap for the design of novel nano-biomaterials that would play a useful role in multidisciplinary fields.
\end{abstract}

Key words_— magnetic particle; magnetotatic bacteria; receptor; display

\section{1. はじめに}

ヒトゲノム計画の目覚ましい進展により，創薬研 究はゲノム研究を基盤としたゲノム創薬へと変貌し つつある．膨大なゲノム情報の中から，疾病に関連 するタンパク質をコードする遺伝子を選択し，遺伝 子組換え技術を用いて，そのタンパク質を生産する ことにより，様々な解析が行えるようになった．特 に，受容体は，物質の認識やシグナル伝達などの場 として生命現象を司る重要な役割を果たしており, 創薬分野において注目を集めている。そのため，大 学・製薬企業等を始め, 世界中の研究機関において 受容体の解析が進められ，医薬品開発の基礎的研究 として位置づけられている.

東京農工大学大学院工学府生命工学専攻（†184-8588 東京都小金井市中町 2-24-16)

*e-mail: y-tomoko@cc.tuat.ac.jp

本総説は, 日本薬学会第 129 年会シンポジウムS05 で 発表したものを中心に記述したものである.
大腸菌を用いた組換えタンパク質生産技術が, 1970 年代後半に開発されて以来, ウイルス, 大腸 菌, 酵母, 及び動物細胞がホスト細胞として用いら れている。これらのホスト細胞を用いた技術は，効 率的な培養方法, 発現制御システム, タンパク質精 製方法など，様々な技術的確立を経て，現在の主流 となっている。「受容体一リガンド」の解析におい ては，受容体を組換えタンパク質として発現させる ことが前提となるが，多くの受容体が膜タンパク質 であるため，その性質は多様であり発現の効率も各 タンパク質の性質に依存している。そのため, 受容 体の種類やその後の用途に合わせて受容体発現用の ホスト細胞や精製方法，また受容体の固相化が検討 されている.

本稿で紹介するタンパク質生産技術は，磁性粒子 上にタンパク質を提示（ディスプレイ）することが できる微生物, 磁性細菌をホスト細胞として用い る。磁性粒子上へタンパク質をディスプレイさせる 
ことにより，目的タンパク質の精製が簡便となり， 磁性粒子自体をタンパク質解析用の固相担体として 用いることができるため，応用範囲が極めて広い． 本稿では，われわれが独自に開発してきたバイオナ ノ磁性粒子上へのタンパク質ディスプレイ技術，及 び受容体解析への応用に関して紹介する。

\section{2. 微生物が合成するナノ磁性粒子}

磁性粒子は，DNA，タンパク質等の生体分子， 又はウイルスや細胞等の回収・検出を始めとし，薬 物を患部に輸送するドラックデリバリーシステムや がんの温熱治療などに幅広く用いられている．磁性 粒子の最大の利点は，磁石により磁気分離・誘導で きることであり，さらにそれらの操作を比較的簡便 に自動化できる点である。計測や分離等の手法では $\mathrm{B} / \mathrm{F}$ 分離 (Bound/Free separation) 操作が可能な 常磁性の磁性粒子が多く用いられている。これは, 磁気回収時にの夕磁化し，それ以外では磁化しない ため，粒子同士の凝集はみられないことから，反応 場として適しているためである. $1 \mu \mathrm{m}$ 以下の常磁 性の磁性粒子では, 磁気回収, $\mathrm{B} / \mathrm{F}$ 分離が困難で あるため, $1 \mu \mathrm{m}$ 前後の粒子が実用化されている.

一方，マグネタイト $\left(\mathrm{Fe}_{3} \mathrm{O}_{4}\right)$ などのフェリ磁性で ある磁性粒子は，水溶液中において磁気的に凝集し てしまうが， $1 \mu \mathrm{m}$ 以下の粒子を用いた場合でも磁 気回収が可能である。したがって，サブミクロンの 磁性粒子を利用する際には，常磁性かつ磁気的な回 収が容易な粒子の利用が望まれる。

菌体内にマグネタイトを合成する微生物，磁性細 菌は大きさ・結晶構造の揃つた磁性粒子（バイオナ 八磁性粒子, Fig. 1) を生合成することが知られる. このユニークな細菌内で起こる磁性粒子合成メカニ ズムに関する研究が，一昨年，Nature と Science に ほぼ同時に報告され，多くの研究者の注目を集めて いる. Magnetospirillum magneticum AMB-1 株に おいては，着磁方向の揃つた単磁区構造を有するフ エリ磁性の磁性粒子を合成する。この磁性粒子は, それぞれがホスファチジルエタノールアミンを中心 とした脂質二重膜で覆われていることより，フェリ 磁性の人工磁性粒子とは異なった挙動を示す。この ような脂質二重膜に覆われた粒子は分散性がよく, また回収率も高いため，様々な検出への応用が可能 となる．また磁性粒子を覆う脂質二重膜中にはいく つかの膜タンパク質が存在しており（Fig. 1)，こ
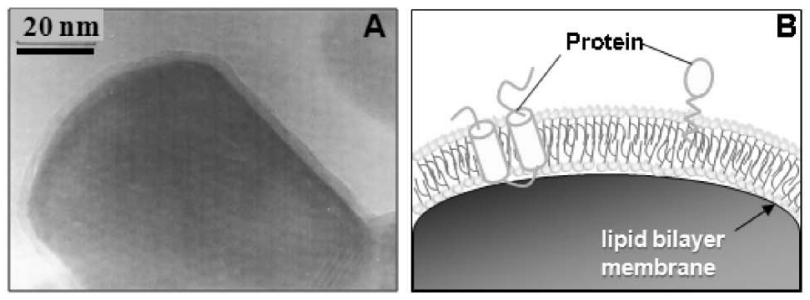

Fig. 1. Transmission Electron Microscopic (TEM) Imaging (A) and Schematic Diagram (B) of a Bacterial Magnetic Particle (BacMP)

れらは細胞質や細胞膜にはみられないバイオナノ磁 性粒子特有の夕ンパク質であることより，マグネタ イトの生成に深く関与していることが示唆されてい る。筆者らは，バイオナノ磁性粒子生成メカニズム の解明に向けて，全ゲノム解析, ${ }^{1)}$ DNA チップによ るトランスクリプトーム解析, ${ }^{2)}$ LC-MS/MS などを 取り入れたプロテオーム解析 ${ }^{3)}$ を推進してきた。 こ れらの解析結果から，生成メカニズムの全貌が明ら かにされるとともに，ここで得られた基礎的知見に 基づいて磁性粒子上へのタンパク質ディスプレイ技 術が開発され，応用技術へと発展してきた。次項目 ではその要素技術に関して紹介する.

\section{3. タンパク質ディスプレイの要素技術}

筆者らは微生物が合成する磁性粒子に着目し，全 く新しい手法を用いて機能を付加したバイオナノ磁 性粒子の創製に着手している. その手法として，バ イオナノ磁性粒子膜上に元来存在するタンパク質を 足場（アンカー）として利用し，遺伝子融合技術に より酵素・抗体・受容体をディスプレイする技術が 開発されている，本技術は融合タンパク質の自由な 設計が可能であり，活性部位を維持した状態で粒子 上へタンパク質をディスプレイすることが可能であ る。これまでに，ルシフェラーゼ, ${ }^{4)}$ ピルビン酸リ ン酸ジキナーゼ5)等の酵素を始め, 抗体結合タンパ ク質であるプロテイン $\mathrm{A},{ }^{6,7)}$ プロテイン $\mathrm{G},{ }^{8)}$ 核内 受容体の 1 つであるエストロゲン受容体, ${ }^{9,10)}$ また 膜貫通タンパク質であるドーパミン受容体 ${ }^{11)}$ のディ スプレイに成功している.

Figure 2 に機能性バイオナノ磁性粒子の作製法を 示す。アンカー遺伝子に目的のタンパク質をコード する遺伝子を融合し，この融合遺伝子を含むプラス ミドを磁性細菌に導入する，得られた磁性細菌の形 質転換体を培養した後，集菌・細胞破砕を行う。そ 


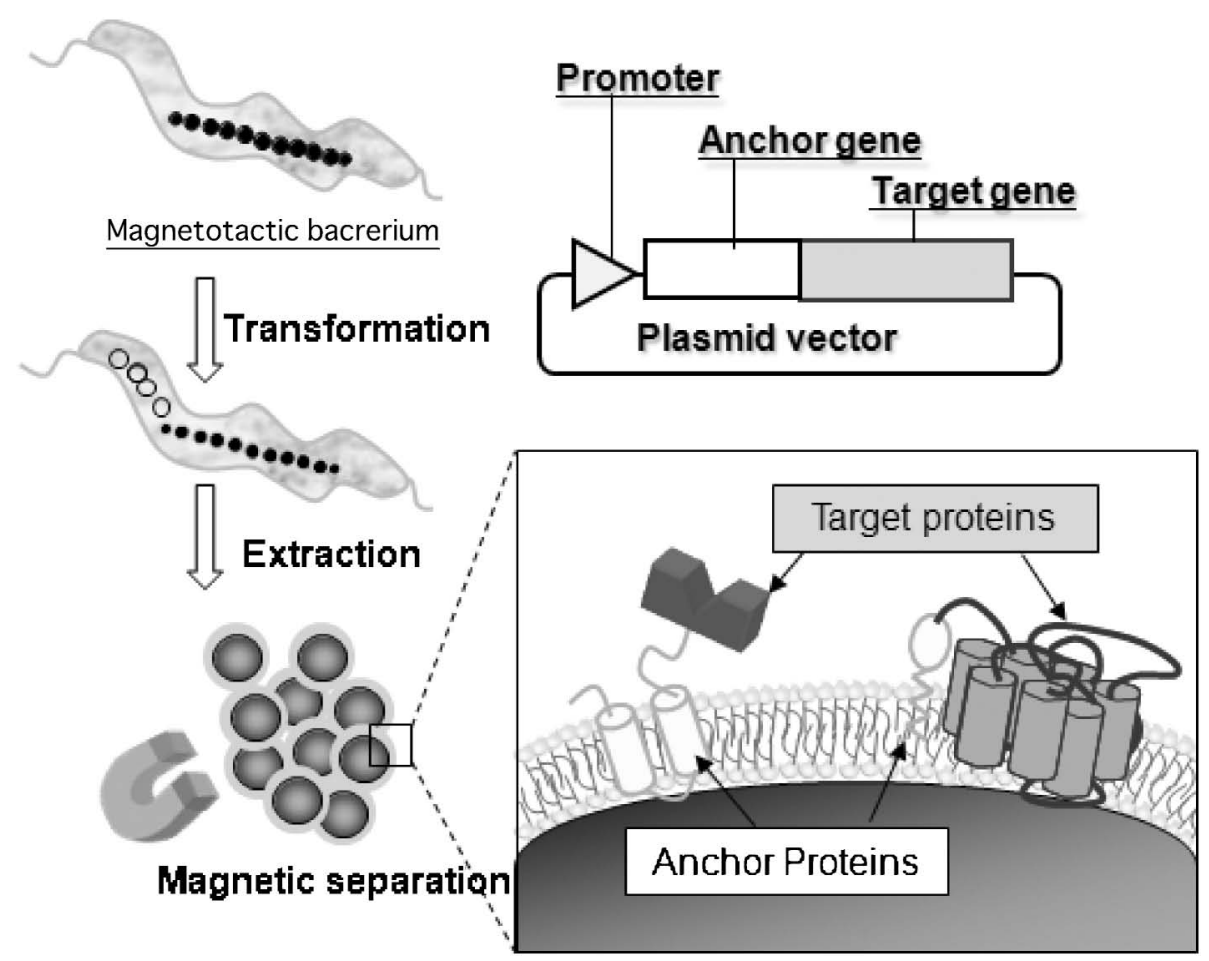

Fig. 2. Schematic Diagram for Preparation of BacMPs Displaying Functional Proteins

の後は破砕物を含む容器に磁石を設置し，未破砕物 の除去・洗浄を行う。上記操作により，様々な機能 性のタンパク質を同一の手法で磁性粒子上にディス プレイすることが可能である．筆者らは，バイオナ ノ磁性粒子の大量調製を目的に，高密度培養法を確 立し，実用化を視野に入れた研究を進めている. ${ }^{12)}$ バイオナノ磁性粒子を各種アプリケーションに利用 するためには，サイズ，形状や磁気特性を追求する だけではなく，分子レベルでの粒子表面設計が重要 であるため，磁性細菌を利用したディスプレイ技術 は大変有効である。さらに，バイオナノ磁性粒子上 への機能性タンパク質のディスプレイ効率やタンパ ク質量の増大を目的として，発現量を調節するプロ モーター因子，及び磁性粒子上への局在化を促進す るアンカー分子の検討が行われている．以下には， バイオナノ磁性粒子上へのディスプレイにおいて要 素技術となる高発現プロモーターとアンカーの探索 について紹介する.

3-1. 高発現プロモーター＼cjkstart磁性細菌内におけ る高発現プロモーターを用いることで, 粒子膜上へ の融合タンパク質のディスプレイ量の増大が期待で きる，そこで, 磁性細菌内で発現量の多いタンパク 質をコードする遺伝子配列の上流に高発現プロモー
ターが存在することを想定し，以下の実験に取り組 んだ。野生株から得られた磁性細菌細胞膜画分の夕 ンパク質を 2 次元電気泳動により分離し, タンパク 質量の多いスポット $(n=6$, Fig. 3$)$ に関して，ア ミノ酸配列同定, ORF の決定, ORF 上流領域（プ ロモーター予想配列）のゲノム DNA からの抽出を 行った。 各プロモーター予想配列をレポーター分子 であるルシフェラーゼ遺伝子の上流に導入し，磁性 細菌内におけるプロモーター活性を評価した。その 結果, Pmms16, Pmsp1, Pmsp3 において, 従来用 いられていたプロモーターP PmagA の 100 倍以上の 高い活性が示された（Table 1)。また， $m s p 3$ のプ ロモーターを使用し，発現強度を変えることで，磁 性粒子膜上への融合タンパク質量の増大に成功し た. ${ }^{13)}$

3-2. アンカー分子 新規アンカー分子の探索 として，磁性粒子上に特異的に発現し，かつ粒子表 面に強固に結合しているタンパク質 ${ }^{14)}$ 着目し，ア ンカー分子としての機能を評価した。 マグネタイト に強固に結合する $13 \mathrm{kDa}$ のタンパク質, $\mathrm{Mms} 13$ は 2 次構造予測により膜 2 回貫通型タンパク質であ ることが予想された。これまで用いられてきたアン カーである MagA（膜 12 回貫通型），Mms16（脂 


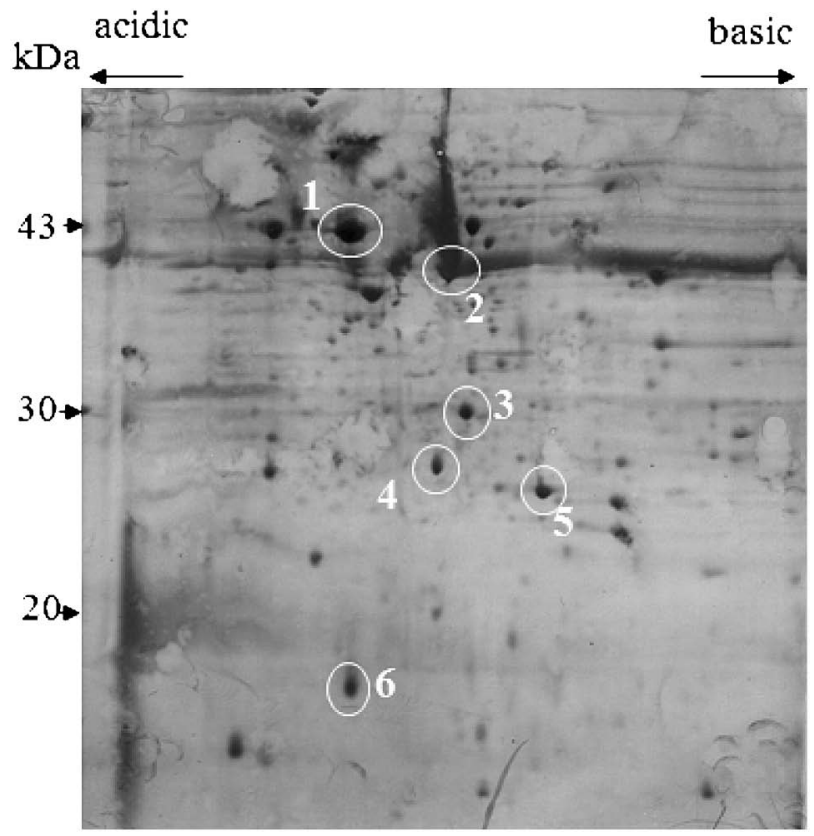

Fig. 3. 2-D-gel Electrophoresis of Cell Membrane Protein Fractions of AMB-1

Circles indicate spots of identified proteins.

Table 1. Luciferase Expression in AMB-1 Transformants Regulated by Each Promoter Sequence

\begin{tabular}{lc}
\hline \hline \multicolumn{1}{c}{ Plasmids } & $\begin{array}{c}\text { Luminescence intensity } \\
\left.\text { (kcount/second } / 8 \times 10^{7} \text { cells }\right)\end{array}$ \\
\hline pUMGLC-PmagA & 37 \\
pUMGLC-Pmms16 & 3399 \\
pUMGLC-Pmms24 & 423 \\
pUMGLC-Pmsp1 & 7164 \\
pUMGLC-Pmsp2 & 117 \\
pUMGLC-Pmsp3 & 14691 \\
pUMG (negative control) & 0 \\
\hline
\end{tabular}

質修飾型）の C 末端にルシフェラーゼを融合し， 粒子上へのルシフェラーゼディスプレイ量を比較し た。その結果, Mms13 をアンカーとすることで, Mms16の 400 倍, MagA の 1000 倍のルシフェラー ゼ活性が示された。この結果は, 磁性細菌内で合成 された粒子上に Mms13 が多量に局在し, かつ粒子 表面に強固に結合していることに起因すると考えら れた。

Mms13 をアンカー分子とし，様々な機能性タン パク質のディスプレイに成功している. $4,5,8,10,15)$ 実 際に抗体の $\mathrm{Fc}$ 部位との結合性を示すプロテイン $\mathrm{A}$ をMms13 と遺伝子融合し，ディスプレイを試み た。蛍光標識抗体により粒子上へのプロテイン A

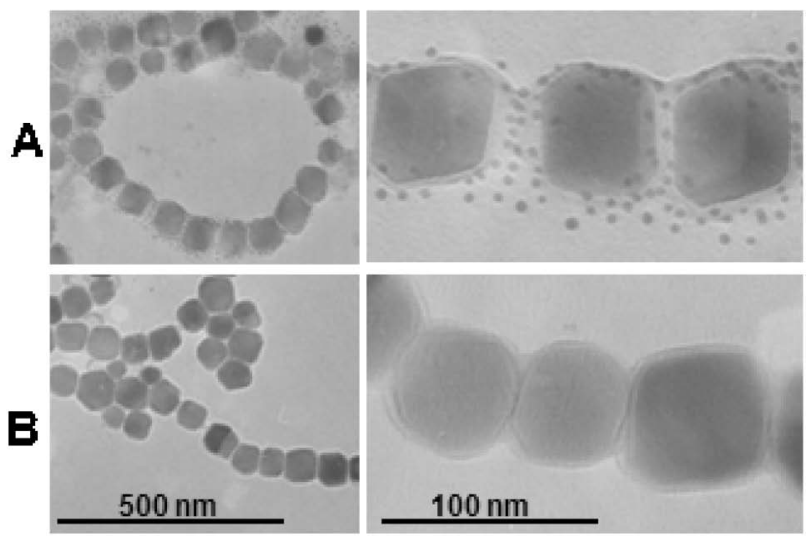

Fig. 4. TEMs of BacMPs Displaying Mms13-Protein A Introduced to Rabbit IgG after Addition of Gold Nanoparticle (5 nm) -labeled Anti-rabbit IgG Antibodies (A) or Anti-human IgG Antibodies (B)

発現の分布を観察したところ，ほぼ 100\%の粒子に 蛍光が観察され，磁性細菌内での粒子合成過程にお いて, Mms13-プロテイン A 融合タンパク質がほと んどすべての粒子上にディスプレイされていること が示された。さらに金ナノ粒子 $(5 \mathrm{~nm})$ 標識の抗 体により， 1 粒子上あたりのプロテイン A の分子 数は，約 20 個であった (Fig. 4).上記のようにア ンカー分子との融合による機能性分子の導入は磁性 細菌が合成する磁性粒子を用いることで可能となる.

\section{4. バイオナノ磁性粒子上への受容体ディスプレ} 1

薬物が作用する標的として, 受容体, 酵素, 輸送 タンパク質, 核酸などが挙げられるが, 多くの薬理 学的応答は受容体を介して調節されるため, 受容体 は創薬分野において非常に重要なタンパク質群であ る。受容体をアミノ酸配列に基づいて分類すること により，少数のサブファミリーが存在することが示 されている，筆者らは，その中でも， $\mathrm{G}$ タンパク 共役型受容体, 及び遺伝子の転写を制御する細胞核 内の受容体に着目して研究を進めている．以下では，

$\mathrm{G}$ タンパク質共役型受容体であるドーパミン受容 体, 核内受容体としてエストロゲン受容体のバイオ ナノ磁性粒子上へのディスプレイに関する研究を示 す.

4-1. ドーパミン受容体医薬品開発の中で大 きなシェアを占める $\mathrm{G}$ タンパク質共役型受容体 （GPCR）は, 細胞内シグナル伝達の制御，細胞の 内外部環境との相互作用の調節など，生命現象の 
キーとなる役割を担っている。このため，疾病との 因果関係も強く，GPCR をターゲットとした医薬 品開発が盛んに行われている。 GPCR は，膜に 7 回貫通したヘリックスドメインを持ち，細胞外側に リガンド結合部位，細胞内側に $\mathrm{G}$ タンパク質が結 合する部位を有するため，その発現・精製方法には 煩雑な操作が必要である。筆者らは，磁性細菌が合 成する脂質二重膜で覆われた磁性粒子が，膜貫通夕 ンパク質の局在場所として利用できることを提唱し ている，著者らは GPCR の 1 つであるドーパミン 受容体（D1R）を用いて，磁性粒子上へのアセンブ リングを試みた. ${ }^{11)}$ 自由度の高い脂質修飾型のタン パク質である Mms16 をアンカー分子として用い, GPCR のフォールディングを助長する設計を行っ た．GPCR のモデルとして D1R を用い，D1R 遺伝 子と Mms16 遺伝子との融合遺伝子を磁性細菌に導 入した。得られた形質転換体を培養・集菌・細胞破 砕後, 磁気分離操作により D1R をアセンブリング した磁性粒子を得た。この粒子上の D1R の解離定 数は $9.75 \mathrm{nM}$ と算出され，ナノオーダーの結合能 を保持していることが明らかとなった。 さらにリガ ンドスクリーニング技術の開発を目的とし，蛍光標 識アンタゴニスト（SCH23390）を用いた競合結合 実験を行った。蛍光標識 SCH23390 存在下で非標 識のドーパミンと競合反応を行ったところ，ドーパ ミンの濃度の上昇に伴い蛍光の減少が観察され, ドーパミンの定量が可能であった（Fig. 5)。磁性 細菌から得られる磁性粒子上への膜受容体ディスプ レイ技術は，簡便な GPCR の調整を可能とし，膜 タンパク質の煩雑な調整法を解決できる有効な手段 を提供できると考えられる。しかしながら，多くの 膜タンパク質において，形質転換効率の低下や膜夕 ンパク質の発現による細胞増殖の阻害といった細胞 への影響も示されている。これは磁性細菌に限ら ず，様々なホスト細胞でも同様である，現在，筆者 らは，磁性細菌のゲノミクス，プロテオミクス等で 得られた知見を基に，効率的な膜タンパク質の発現 技術の開発に取り組んでいる。

4-2.エストロゲン受容体核内受容体は，脂 溶性の生理活性物質をリガンドとするリガンド誘導 性転写制御因子である。リガンドと結合し複合体形 成した核内受容体は核内に移行し，標的遺伝子のプ ロモーター領域にある応答配列（Hormone re-

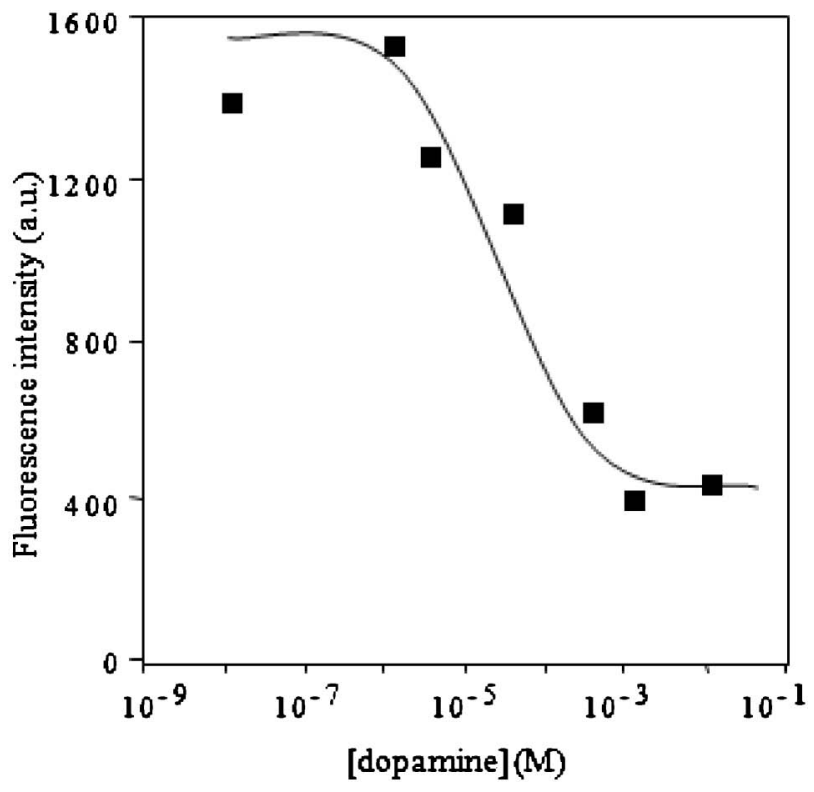

Fig. 5. Fluorescence Competition Binding Analysis of Dopamine to Dopamine Receptors (D1R) on BacMP Surfaces

BacMPs displaying D1R were incubated with BODIPY labeled $\mathrm{SCH} 23390$.

sponse element；HRE）と特異的に結合することで 標的遺伝子の発現を制御する。核内受容体を介した 遺伝子発現調節は，個体発生や器官形成，標的器官 の機能維持など高次の生命現象を制御していると考 えられる，近年，核内受容体とがん，糖尿病，高脂 血症，動脈硬化といつた生活習慣病との関連性が指 摘されている。これらの受容体に対してリガンド作 用を持つ物質は，上記疾病の原因因子となる一方 で，その治療薬としても利用することができる．ま た，近年，核内受容体の 1 つであるエストロゲン受 容体（ER）の転写制御に関しての解明が進み，細 胞種の違いにより応答する標的遺伝子が異なること

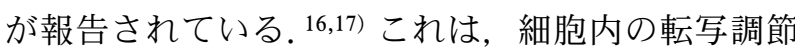
因子機構によるものと考えられているが，いまだ詳 しいメカニズムは解明されていない。子宮，卵巣， 胸腺などのエストロゲン標的細胞においても，各細 胞内では異なる転写調節因子であるコアクチベー ターが発現していることが分かっており，このよう なコアクチベーター発現の違いががん等の治療効果 に大きな影響を与えていることが分かってきた．乳 がんの抑制剤として用いられる Tamoxifen は，子 宮内の細胞内ではアゴニストとして働き，子宮内膜

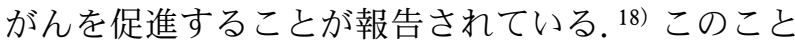
から、コアクチベーターの違いによる ER 応答遺伝 
子の異なる転写調節が予測される。これらの ER が 関与する標的遺伝子の転写制御を解明することによ り，目的のエストロゲン標的細胞のみに作用する腫 瘍抑制剤の作製が可能であると考えられる。

筆者らは，ER，リガンド，コアクチベーターの 複合体形成を in vitro で再現することにより，ER のアゴニスト活性を示す化学物質評価法の開発を行 っている（Fig. 6)。Mms13をアンカータンパク質 として用い，ERのリガンド結合部位である ERLBD を磁性粒子上にディスプレイした。ささらに 大腸菌 BL21 を用いて steroid receptor coactivator-1 の NRBOX 部位と GFP を融合した融合タンパク質 GFP-coactivator を作製した。次に Estradiol (E2), 及び GFP-coactivator を, ERLBD をディスプレイ した磁性粒子と反応させ，GFP 由来の蛍光強度を 測定した。その結果，E2 依存的に GFP-coactivator が結合していることが示された。 そこで，ERに対 する強アゴニスト (E2, estriol)，弱アゴニスト (Octylphenol)，アンタゴニスト（ICI 182780）に 対して同様の評価を行ったところ，強アゴニストに おいては E2 と同様の蛍光強度を示したが，弱アゴ ニストでは E2 に対して $40 \%$ の蛍光強度の増加があ り，アンタゴニストでは蛍光強度の増加はみられな かった（Fig. 7)。このことから，磁性粒子上にお いて，複合体を形成することで受容体に対する親和 性の違いを識別可能な化学物質評価法の構築が示さ れた。またバイオナノ磁性粒子を用いて反応から測
定過程までの自動化に成功していることから, 19,20 ハイスループットな受容体解析が行えると考えられ る.

\section{5. おわりに}

本総説では，磁性細菌をホスト細胞とした磁性粒 子上へのタンパク質ディスプレイ技術に関して紹介 した。磁性細菌を対象とした基礎研究においては, 近年，研究グループが増加し，磁性粒子合成メカニ ズムの解明につながる研究がさかんに行われてい る。一方，磁性細菌をタンパク質発現用のホスト細

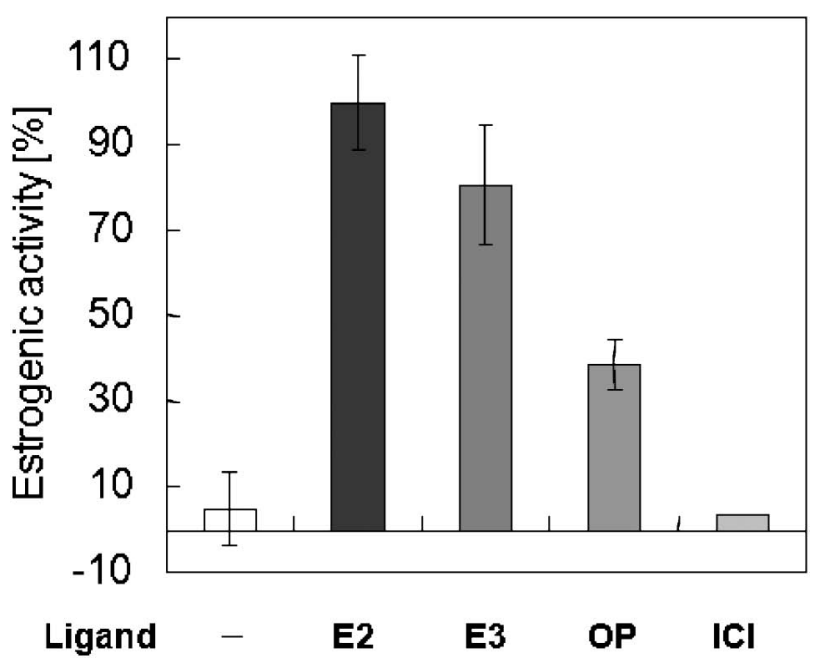

Fig. 7. Binding Assay of GFP-coactivator and Each Ligand to ERLBD-BacMPs

Ligand concentration: $10^{-6} \mathrm{M}, \mathrm{E} 2$ : Estradiol, E3: Estriol, OP: Octylphenol, ICI: ICI 182780.

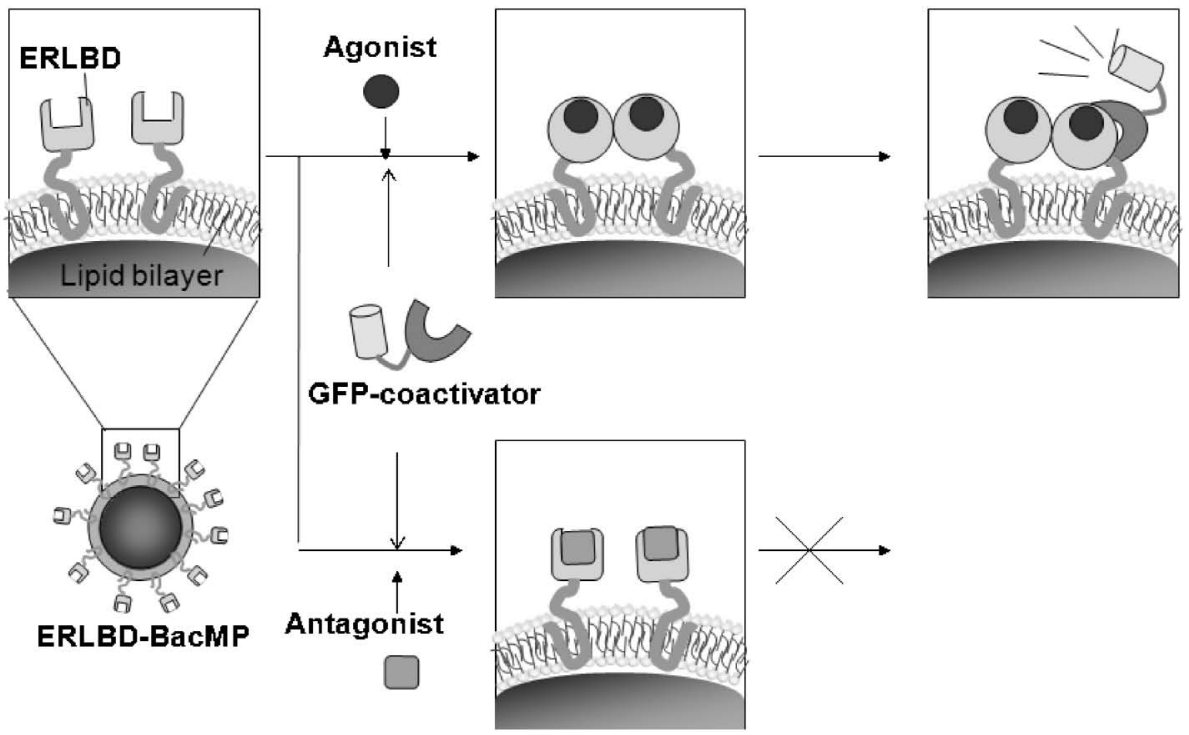

Fig. 6. Schematic Diagram of the GFP-coactivator Recruitment Assay 
胞として用いる研究に関しては，筆者らが展開して きた研究であり，基盤技術の整備を独自に行ってき た．本手法は，目的の遺伝子さえ手に入れば，同一 の手法で磁性粒子上にタンパク質をディスプレイす ることができ，細胞破砕後，磁気分離操作のみで精 製が完了する非常に優れた研究技術と言える．今後 は，複雑な構造を持つタンパク質を効率よくディス プレイする技術の確立が課題である.

磁性細菌を用いることで, 分子生物学的手法によ る機能性バイオナノ磁性粒子の創製が可能であり, その応用範囲は医療分野に留まらず，食品，さらに 環境分野まで多岐にわたる。遺伝子やタンパク質を 始め，分子レベルで解析された情報を基にナノマテ リアルを創製し，工学的に応用することが，今後も ますます重要になっていくと考えられる.

\section{REFERENCES}

1) Matsunaga T., Okamura Y., Fukuda Y., Wahyudi A., Murase Y., Takeyama T., DNA Res., 12, 157-166 (2005).

2) Suzuki T., Okamura Y., Calugay R. J., Takeyama H., Matsunaga T., J. Bacteriol., 188, 2275-2279 (2006) .

3) Tanaka T., Okamura Y., Arakaki A., Tanaka T., Takeyama H., Matsunaga T., Proteomics, 6, 5234-5247 (2006)

4) Yoshino T., Matsunaga T., Appl. Environ. Microbiol., 72, 465-471 (2006).

5) Yoshino T., Nishimura T., Mori T., Suzuki S., Kambara H., Takeyama H., Matsunaga T., Biotechnol. Bioeng., 103, 130-137 (2009).

6) Kuhara M., Takeyama H., Tanaka T., Matsunaga T., Anal. Chem., 76, 6207-6213 (2004)

7) Yoshino T., Hirabe H., Takahashi M., Kuhara M., Takeyama H., Matsunaga T., Biotechnol. Bioeng., 101, 470-477 (2008).
8) Takahashi M., Yoshino T., Takeyama H., Matsunaga T., Biotechnol. Prog., 25, 219-226 (2009).

9) Yoshino T., Kato F., Takeyama H., Nakai M., Yakabe Y., Matsunaga T., Anal. Chim. Acta, 532, 101 (2005)

10) Yoshino T., Kaji C., Nakai M., Saito F., Takeyama H., Matsunaga T., Anal. Chim. Acta, 626, 71-77 (2008).

11) Yoshino T., Takahashi M., Takeyama H., Okamura Y., Kato F., Matsunaga T., Appl. Environ. Microbiol., 70, 2880-2885 (2004)

12) Yang C. D., Takeyama H., Matsunaga T., $J$. Biosci. Bioeng., 91, 213-216 (2001).

13) Yoshino T., Matsunaga T., Biochem. Biophys. Res. Commun., 338, 1678-1681 (2005).

14) Arakaki A., Webb J., Matsunaga T., J. Biol. Chem., 278, 8745-8750 (2003)

15) Maeda Y., Yoshino T., Takahashi M., Ginya H., Aasahina J., Tajima H., Matsunaga T., Appl. Environ. Microbiol., 74, 5139-5145 (2008).

16) Laganiere J., Deblois G., Lefebvre C., Bataille A. R., Robert F., Giguere V., Proc. Natl. Acad. Sci. USA, 102, 11651-11656 (2005).

17) Zhang H., Yi X., Sun X., Yin N., Shi B., Wu H., Wang D., Wu G., Shang Y., Genes Dev., 18, 1753-1765 (2004).

18) Jordan V. C., Gapstur S., Morrow M., J. Natl. Cancer Inst., 93, 1449-1457 (2001).

19) Matsunaga T., Maruyama K., Takeyama H., Katoh T., Biosens. Bioelectron., 22, 23152321 (2007).

20) Matsunaga T., Maeda Y., Yoshino T., Takeyama H., Takahashi M., Ginya H., Aasahina J., Tajima H., Anal. Chim. Acta, 597, 331-339 (2007). 